\title{
Optimization of morphometric indexes of seedling of a pine
}

\author{
Yu. Savchenko, \\ I. Grygoriuk, \\ Corresponding Member of the National Academy of Sciences of Ukraine, Doctor of Biological \\ National University of Life and Environmental Sciences of Ukraine
} Sciences

The purpose. To determine stimulating effect of combined fertilizers and biostimulants of propagation upon morphometric indexes of annual seedlings of pine, grown in film glasshouse. Methods. Field - for determination of quantity indicators of edaphic germinating ability, preservation of plants of pine; laboratory - for study of morphometric indexes of seedlings, length and mass of above-ground and rooted parts; mathematical - for calculation of ratio between mass of above-ground part to mass of rootage; statistical for analysis of reliability of the gained results of probes. Results. Changes in morphometric indexes of annual seedlings of pine under impact of combined fertilizers and biostimulants of propagation are shown. Conclusions. Multicomponent fertilizers in combination with biostimulants of propagation manifest stimulating effect on germinating ability, preservation and formation of seedlings of pine in hothouse conditions.

Key words: pine, seedlings, combined fertilizers, biostimulants of propagation, germinating ability, preservation.

Under the influence of biogenic and anthropogenic stress factors pine plantations serve as the powerful barrier and filter between the environment and man. The rainfalls are reduced and the water deficiency is increasing because of the climate changes. Now this problem is actual in Ukraine and worldwide [5]. Pine (Pinus sylvestris L.) belongs to widely areolar and highly pliable species, that is the basis of species composition of forests in Ukraine, majority of which gradually degrades and needs reforestation cutting, followed by reforestation [3].

Thus, at present the most urgent is the issue of development of new highly efficient and environmentally friendly technologies that are able to intensify the processes of growth and formation of high-quality planting of pine [4].

This problem can be solved by applying new highly efficient multi-fertilizers such as "Avatar-1" and "Bioyodis" in combination with growth stimulators of broad spectrum - "Regoplant" and "Stimpo", that allows to regulate metabolic processes directly, to mobilize incorporated potential opportunities laid down in the genome, to improve plant resistance against moisture deficiency, low and high temperatures [2].

The purpose of research - to determine the effect of stimulating complex fertilizers and bio-stimulants of growth on morphometric parameters of annual plants pine seedlings in greenhouse.

Materials and methods of research. Studies were part of a series of experiments using modern composite fertilizers and bio-stimulants of growth under conditions of growing plant material plant pine. The work performed at the arboretum of Kupyansk Forestry State Enterprise "Kupiansk forestry" Kharkiv region in 2014-2015 biennium.

The object of the study were one-year pine seedlings that were grown in stationary unheated spring and summer greenhouse with plastic coating, equipped wih the stationary atomizing irrigative system in compliance with the rules for operation and regulation of microclimate. The humidity of the substrate was continuously maintained within $50-60 \%$ of the total water capacity. As a substrate using freshly prepared mixture of sandy upper horizon from the tent pine plantations and local lowland peat milling workpiece.

Pre-seed processing performed within 18 hours in aqueous bio-stimulants growth "Regoplant" and "Stimpo" in concentrations of 0.5, 1.0, 1.5, 2.0 and $2.5 \mathrm{ml} / \mathrm{L}$, complex fertilizers "Avatar-1" and "Bioyodis" - 
$2.5,5.0,10.0,15.0 \mathrm{ml} / \mathrm{l}$ and mixtures in optimal concentrations "Regoplant" (1.5 ml/l) + "Avatar-1" (5 ml/l), "Regoplant" (1 $5 \mathrm{ml} / \mathrm{l})$ + "Bioyodis" (10 ml/l), "Stimpo" (2.0 ml/l) + "Avatar-1" (5 ml/l), "Stimpo" (2.0 ml/l) + "Bioyodis" (10 ml/l). Pre-treatment of seeds in water as a control/

Seeds were sown during achieving top layer of greenhouse substrate temperature $+6-7^{\circ} \mathrm{C}$. During the studies measured soil germination in 21 days, survival of crops in autumn - 180 th, morphometric parameters of seedlings spring 360 th day, as well as the length of the ground part and root system $(\mathrm{cm})$ thick root collar $(\mathrm{mm})$, weight of aerial parts and root $(\mathrm{g})$. Calculated as indicator plants grown as the ratio of the mass of the weight of the aerial parts to weight of the root system seedling of pine as follows:

$$
C=\frac{M a}{M r}
$$

where $C$ - the ratio of the mass of the aerial parts to weight of the root system seedling of pine;

$\mathrm{Ma}$ - weight of the aerial parts of seedlings, g;

$\mathrm{Mr}$ - weight of the root system of seedling, $\mathrm{g}$.

Every variant of the experiment included 200 even-aged seedlings, repetition - quadruple. The results are statistically processed by methods of variation statistics ANOVA.

Results. The soil germination and survival are the main quantitative indicators of morphometric parameters of Scots pine seedlings. The using of complex fertilizers and biostimulants of growth resulted a significant stimulating effect on the growth and development of plants of Scots pine seedlings (Table. 1). Under these conditions observed a linear dependence between the dose and obtained effect.

In this way, the best concentration for pre-treatment plant seedlings of Scots pine of growth biostimulants "Regoplant" or "Stimpo" are $2.0 \mathrm{ml} / \mathrm{l}$, multicomponent fertilizers "Avatar-1" - 5.0 and "Bioyodis" - $10 \mathrm{ml} / \mathrm{l}$ of water .

By the indicator of soil germination was observed a significant increase in the number of sprouted seeds in versions of preparations Stimpo $(2.0 \mathrm{ml} / \mathrm{l})$ by $6.1 \%$ and Avatar- $1(5.0 \mathrm{ml} / \mathrm{l})$ to the $5.6 \%$ for control. Among the mixes of preparations the most soil germination was found in the variant Stimpo $(2.0 \mathrm{ml} / \mathrm{l})+$ Avatar-1 $(5$ $\mathrm{ml} / \mathrm{l})$, which accounted for $15.3 \%$ for the control.

The autumn dimensions was found a similar dependence of the number of surviving of Scots pine seedlings in variant Stimpo $(2.0 \mathrm{ml} / \mathrm{l})-7.4 \%$, Avatar-1 - $(5.0 \mathrm{ml} / \mathrm{l})-6.8$, and mixtures of Stimpo $(2,0 \mathrm{ml} / \mathrm{l})+1$ Avatar-1 (5 ml/l) $-10.1 \%$ for the control. It is obvious that the use of mixtures of preparations Stimpo $(2.0$ $\mathrm{ml} / \mathrm{l})+$ Avatar-1 ( $5 \mathrm{ml} / \mathrm{l})$ for the pre-treatment of seeds leads to increase in the number out plant material by $27 \%$ as compared with the control.

1. The efficiency of influence growth biostimulants and complex of fertilizers on the morphometric parameters annual seedlings of Scots pine

\begin{tabular}{|c|c|c|c|c|c|c|c|c|}
\hline \multirow[b]{2}{*}{$\begin{array}{l}\text { № } \\
\text { Vari } \\
\text { ant }\end{array}$} & \multirow{2}{*}{$\begin{array}{l}\text { Complex of fertilizers, } \\
\text { growth biostimulants and } \\
\text { mixtures }\end{array}$} & \multirow{2}{*}{$\begin{array}{l}\text { Spring- } \\
\text { summer } \\
\text { (21 days) } \\
\\
\begin{array}{l}\text { Germination, } \\
\%\end{array}\end{array}$} & \multirow{2}{*}{$\begin{array}{l}\text { Autumn } \\
\text { period } \\
(180 \\
\text { days }) \\
\\
\text { Survival, } \\
\%\end{array}$} & \multicolumn{5}{|c|}{$\begin{array}{l}\text { Morphometric parameters of the } \\
\text { seedlings in spring } \\
\text { ( } 360 \text { days) }\end{array}$} \\
\hline & & & & 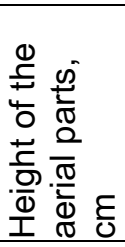 & 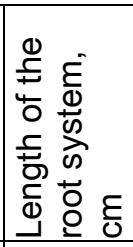 & 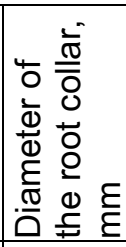 & 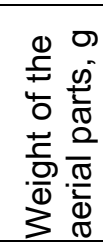 & 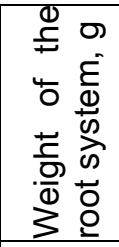 \\
\hline 1 & $\begin{array}{l}\text { Control, treatment of } \\
\text { seeds in water }\end{array}$ & $85,0 \pm 3,5$ & $81,0 \pm 3,4$ & 10,6 & 17,7 & 2,0 & 1,05 & 0,32 \\
\hline 2 & Regoplant $(0,5 \mathrm{ml} / \mathrm{l})$ & $82,0 \pm 3,1$ & $79,2 \pm 3,3$ & 10,8 & 17,7 & 2,1 & 1,10 & 0,33 \\
\hline 3 & Regoplant $(1,0 \mathrm{ml} / \mathrm{l})$ & 85,5 & 80,5 & 11,3 & 17,6 & 2,2 & 1,23 & 0,37 \\
\hline 4 & Regoplant $(1,5 \mathrm{ml} / \mathrm{l})$ & $85,9 \pm 2,3$ & $83,5 \pm 2,2$ & 12,0 & 18,1 & 2,1 & 1,34 & 0,39 \\
\hline 5 & Regoplant $(2,0 \mathrm{ml} / \mathrm{l})$ & $87,4 \pm 2,1$ & $82,0 \pm 3,0$ & 12,7 & 18,6 & 2,2 & 1,52 & 0,40 \\
\hline 6 & Regoplant $(2,5 \mathrm{ml} / \mathrm{l})$ & $85,2 \pm 2,7$ & $82,2 \pm 3,4$ & 11,3 & 17,8 & 2,3 & 1,23 & 0,38 \\
\hline 7 & Stimpo $(0,5 \mathrm{ml} / \mathrm{l})$ & $84,5 \pm 3,5$ & $80,6 \pm 3,2$ & 11,0 & 17,9 & $\overline{2,2}$ & 1,16 & 0,34 \\
\hline 8 & Stimpo $(1,0 \mathrm{ml} / \mathrm{l})$ & $85,2 \pm 3,3$ & $81,0 \pm 3,0$ & 11,4 & 18,1 & 2,2 & 1,25 & 0,38 \\
\hline
\end{tabular}




\begin{tabular}{|c|c|c|c|c|c|c|c|c|}
\hline 9 & Stimpo $(1,5 \mathrm{ml} / \mathrm{l})$ & $87,7 \pm 2,5$ & $83,3 \pm 2,8$ & 12,4 & 18,5 & 2,3 & 1,45 & 0,41 \\
\hline 10 & Stimpo $(2,0 \mathrm{ml} / \mathrm{l})$ & $90,2 \pm 2,0$ & $87,0 \pm 2,6$ & 13,3 & 19,2 & $\overline{2,2}$ & 1,66 & 0,43 \\
\hline 11 & Stimpo $(2,5 \mathrm{ml} / \mathrm{l})$ & $85,2 \pm 2,8$ & $82,2 \pm 3,1$ & 11,6 & 18,0 & 2,1 & 1,25 & $\overline{0,40}$ \\
\hline 12 & Avatar-1 $(2,5 \mathrm{ml} / \mathrm{l})$ & $84,7 \pm 3,3$ & $82,0 \pm 2,9$ & 11,8 & 17,7 & 2,2 & 1,26 & 0,38 \\
\hline 13 & Avatar-1 $(5,0 \mathrm{ml} / \mathrm{l})$ & $89,8 \pm 1,3$ & $86,5 \pm 1,5$ & 13,1 & 18,8 & 2,3 & 1,57 & $\underline{0,42}$ \\
\hline 14 & Avatar-1 $(10,0 \mathrm{ml} / \mathrm{l})$ & $\overline{85,5 \pm 3,0}$ & $\overline{83,2 \pm 2,1}$ & $\overline{12,3}$ & $\overline{18,4}$ & $\overline{2,1}$ & $\overline{1,39}$ & $\overline{0,39}$ \\
\hline 15 & Avatar-1 $(15,0 \mathrm{ml} / \mathrm{l})$ & $84,2 \pm 3,3$ & $80,1 \pm 2,8$ & 11,8 & 18,5 & 2,1 & 1,18 & 0,34 \\
\hline 16 & Bioyodis $(2,5 \mathrm{ml} / \mathrm{l})$ & $83,7 \pm 1,3$ & $79,7 \pm 3,2$ & 10,9 & 17,4 & 2,0 & 1,10 & 0,33 \\
\hline 17 & Bioyodis $(5,0 \mathrm{ml} / \mathrm{l})$ & $85,2 \pm 2,1$ & $83,0 \pm 2,1$ & 11,3 & 18,8 & 2,2 & 1,23 & 0,35 \\
\hline 18 & Bioyodis $(10,0 \mathrm{ml} / \mathrm{l})$ & $86,8 \pm 2,3$ & $81,6 \pm 2,3$ & 12,1 & $\overline{18,6}$ & 2,3 & 1,33 & $\underline{0,38}$ \\
\hline 19 & Bioyodis $(15,0 \mathrm{ml} / \mathrm{l})$ & $84,3 \pm 2,5$ & $81,0 \pm 2,2$ & $\overline{11,6}$ & 18,1 & $\overline{2,1}$ & $\overline{1,16}$ & $\overline{0,35}$ \\
\hline 20 & 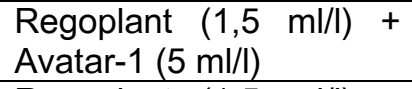 & $93,2 \pm 2,1$ & $86,3 \pm 2,4$ & 13,5 & 19,0 & 2,4 & 1,70 & 0,44 \\
\hline 21 & $\begin{array}{l}\text { Regoplant }(1,5 \mathrm{ml} / \mathrm{l})+ \\
\text { Bioyodis }(10 \mathrm{ml} / \mathrm{l})\end{array}$ & $89,5 \pm 2,6$ & $84,0 \pm 3,1$ & 13,2 & 18,7 & 2,2 & 1,58 & 0,41 \\
\hline 22 & $\begin{array}{lll}\text { Stimpo } & (2,0 & \mathrm{ml} / \mathrm{l})\end{array}$ & $\underline{98,0 \pm 2,0}$ & $\underline{89,2 \pm 1,9}$ & 14,9 & $\underline{19,5}$ & 2,4 & 1,91 & $\underline{0,47}$ \\
\hline 23 & $\begin{array}{lll}\text { Stimpo }(2,0 \mathrm{ml} / \mathrm{l}) & + \\
\text { Bioyodis }(10 \mathrm{ml} / \mathrm{l}) & \end{array}$ & $91,5 \pm 2,7$ & $87,7 \pm 2,5$ & 13,9 & 19,2 & $\underline{2,5}$ & 1,70 & 0,45 \\
\hline \multicolumn{2}{|c|}{ Standard deviation } & - & - & 0,5 & 0,7 & 0,1 & 0,07 & 0,02 \\
\hline
\end{tabular}

In 360 day of the experiment we done linear measurements of morphometric parameters seedlings which the variant of pre-treatment of preparation Stimpo $(2.0 \mathrm{ml} / \mathrm{l})+1$ Avatar-1 $(5 \mathrm{ml} / \mathrm{l})$ revealed a significant increase in the length of the aerial parts of plants $40.6 \%$ to the control, root system - 10.2, Diameter of the root collar $-20 \%$. The growth of the size was accompanied by accumulation of vegetative mass of plants seedlings of Scots pine (Pic. 1).

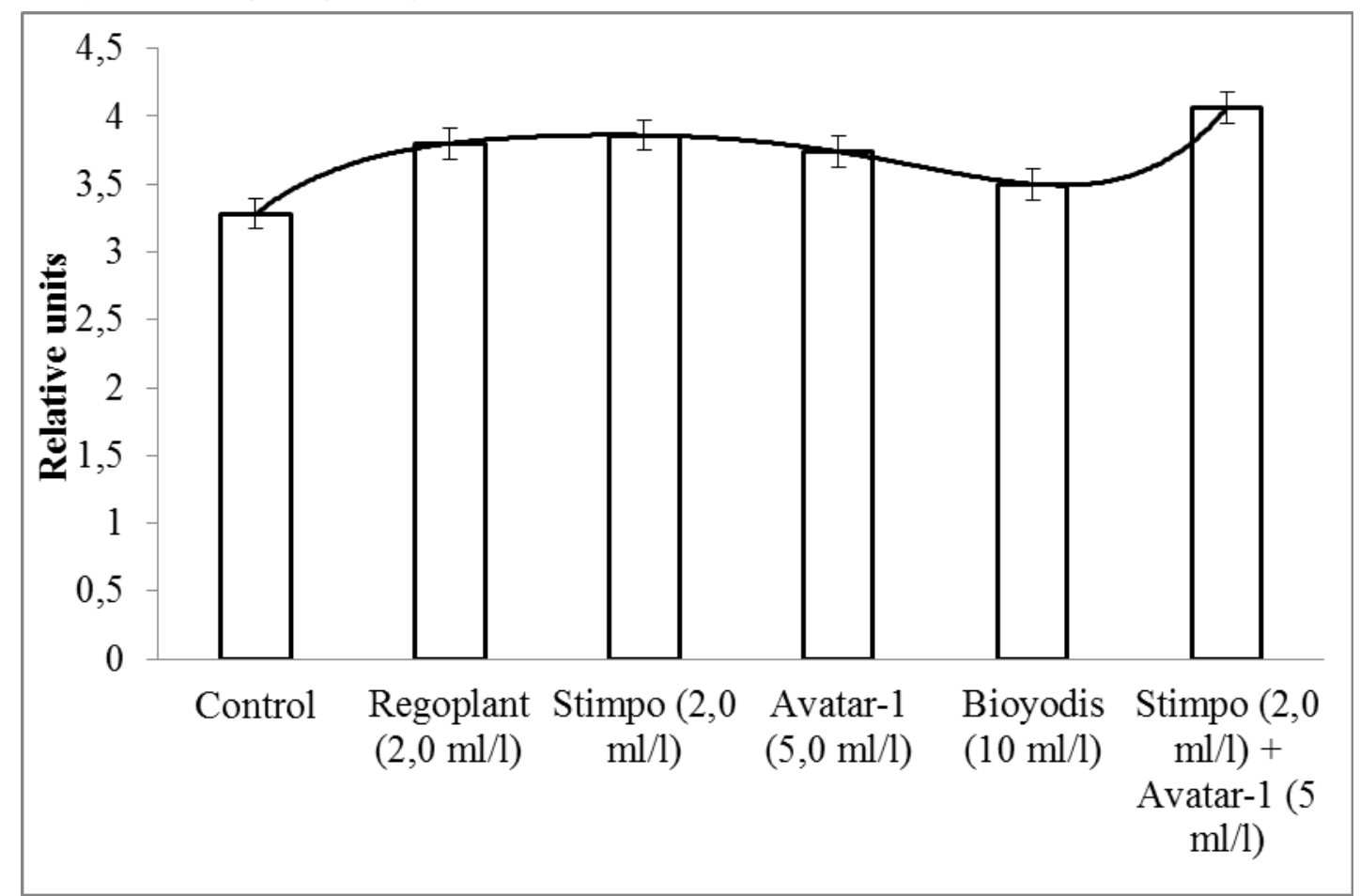

Pic. 1. The ratio of weight of the aerial parts and to the root system of Scots pine seedlings, which processed of growth biostimulants

Calculated the ratio of the mass of aerial annual to the mass of the root system of Scots pine seedlings, as an integral indicator of the quality formation planting material. It is established that the plants seedlings wich processed the biostimulants of growth "Regoplant" and "Stimpo" increase the intensive accumulation biomass than the control. 


\section{Conclusions}

The presowing treatment of the seeds for 18 hours. in aqueous solutions of biostimulators of growth "Regoplant" and "Stimpo", multicomponent microfertilizers "Avatar-1" and "Bioyodis" and it mixtures in the optimal concentrations causes for reliable activation of the formation plant seedlings of Scots pine. The optimal concentration for the pre-treatment of seeds of Scots pine of biostimulants of growth "Regoplant" and "Stimpo" is $2.0 \mathrm{ml} / \mathrm{l}$ fertilizer "Avatar 1" and "Bioyodis" 5.0 and $10 \mathrm{ml} / \mathrm{l}$. The results is topical for optimizing of morphometric parameters, improving germination and growth of annual seedlings of Scots pine in the greenhouse conditions.

\section{Bibliography}

1. Biostymuljatory (reguljatory rostu) roslyn. - DPMNC «Agrobioteh», 2013-2014. - $29 \mathrm{~s}$.

2. Bulygin S. Ju. Mikrojelementy v sel'skom hozjajstve [Bulygin S. Ju., Demishev L. F., Doronin V. A. i dr.] - Dnepropetrovsk: Sich, 2007. - $100 \mathrm{~s}$.

3. Gensiruk S. A. Lisy - bagatstvo i okrasa Zemli. - K. : Nauk. dumka, 1980. - $211 \mathrm{~s}$.

4. Debrynjuk Ju. M. Lisove nasinnyctvo/Ju. M. Debrynjuk, M. I. Kalinin, M. M. Guz', I. V. Shablij - L'viv: Svit, 1998. - $432 \mathrm{~s}$.

5. Mel'nyk V. Y. Redkye vydy flory ravnynnyh lesov Ukrayny/V. Y. Mel'nyk. - K. : Fytosocyocentr, 2002. $299 \mathrm{~s}$.

6. Obodjans'kyj M. A. Reguljator rostu Vermystym - efektyvnyj zasib pidvyshhennja vrozhajnosti jarogo jachmenju/M. A. Obodjans'kyj//Zbirnyk naukovyh prac' Podil's'kogo derzhavnogo agrarno-tehnichnogo universytetu. - 2011. - Vyp. 19. - S. 82 - 85.

7. Pat. na korysnu model' 38230 Ukraïna, MPK (2006) B01J 2/02, B01J 13/00, B22F 9/00. Sposib otrymannja nanochastynok elektroprovidnyh meterialiv i koloïdnyh rozchyniv nanochastynok elektroprovidnyh meterialiv «Plazmova abljacija»/Kosinov M. V., Kaplunenko V. G.; zajavnyk i patentovlasnyk Kosinov M. V., Kaplunenko V. G. - № u 200810197; zajav. 08.08.2008 : opubl. 25.12.2008, Bjul. №24.

8. Pidvyshhennja reguljatoramy rostu imunitetu roslyn do patogennyh grybiv, shkidnykiv i nematod/[Cygankova V. A., Andrusevych Ja. V., Babajanc O. V., Ponomarenko S. P., Medkov A. I., Galkin A. P.]//Fiziologija i biohimija kul'turnyh rastenij. — 2013. — T. 45, № 2. — S. 138-147.

9. Funkcional'ni nanobiomaterialy dlja potreb sil's'kogo gospodarstva/[Kopilevych V. A., Maksin V. I., Kaplunenko V. G., Kosinov M. V.]//Naukovyj visnyk Nacional'nogo agrarnogo universytetu. - 2008. - Vyp. 130. - S. $349-354$.

10. Evaluation of biological activity of microelement complex "Avatar-2" for its application for pre-treatment of wheat seeds/[Davydova O. E., Axylenko M. D., Maksin V. I., Kotenko S. I., Derevianko K. Y., Nikolaevska V. I .]/Bioresursy i pryrodokorystuvannja. - 2014. -6, № 5-6. - C. $72-78$. 